\title{
Pendidikan Kesehatan Upaya Pencegahan Penyakit Demam Berdarah di Lingkungan Sekolah
}

\section{Eka Arie Yuliyani ${ }^{1}$, Rika Hastuti Setyorini' ${ }^{2}$, Eva Triani ${ }^{3}$, Putu Suwita Sari ${ }^{4}$, Indana Eva Ajmala ${ }^{5}$}

${ }^{1}$ Department of ENT, Medical Faculty of Mataram University ${ }^{2}$ Department of Public Health Medicine, Medical Faculty of Mataram University ${ }^{3,4}$ Department of Parasitology, Medical Faculty of Mataram University ${ }^{5}$ Department of Pulmonology, Medical Faculty of Mataram University

Alamat korespondensi : yuliyani.eka@gmail.com

\begin{abstract}
ABSTRAK
Demam berdarah dengue adalah salah satu penyakit berbasis lingkungan yang dapat dicegah dengan melakukan pengendalian vektor. Vektor penyakit DBD yaitu nyamuk Aedes aegypti merupakan spesies kosmopolitan yang banyak ditemukan di berbagai belahan dunia. Munculnya penyakit ini berkaitan dengan kondisi lingkungan dan perilaku masyarakat. Demam Berdarah Dengue merupakan salah satu penyakit dengan potensi menyebabkan fatalitas cukup tinggi. Sebagian besar kasus DBD menyerang anak - anak. Tujuan: Kegiatan pengabdian ini dilakukan dengan memberikan pendidikan kesehatan berupa edukasi melalui permainan Board game kepada guru dan siswa di lingkungan sekolah. Informasi yang disampaikan pada kegiatan ini diharapkan dapat meningkatkan pengetahuan guru dan siswa tentang penyakit demam berdarah dan pencegahannya serta diharapkan terjadi peningkatan sikap dan perilaku dalam hidup bersih dan peduli lingkungan. Metode: Kegiatan ini diikuti oleh 34 orang peserta yang terdiri dari guru dan siswa. Siswa dan guru sangat antusias untuk berpartisipasi dalam kegiatan penyuluhan dalam bentuk permainan ini. Hasil: Di kalangan anak usia Sekolah Dasar kegiatan ini diterima dengan sangat baik dari pihak sekolah karena mereka mendapatkan edukasi mengenai penyakit Demam Berdarah dalam bentuk yang sangat menyenangkan sehingga para siswa tidak merasa jenuh.
\end{abstract}

Kata kunci: Demam Berdarah Dengue, Board game, siswa Sekolah Dasar

\section{PENDAHULUAN}

Penyakit Demam Berdarah Dengue masih menjadi permasalahan kesehatan baik di wilayah perkotaan maupun wilayah semi - perkotaan. Penyakit ini berhubungan dengan perilaku vektor dan keadaan lingkungan seperti iklim, pengendalian vektor, urbanisasi sehingga hal tersebut berpengaruh terhadap terjadinya wabah demam berdarah (Nazri,dkk., 2013). Demam Berdarah Dengue merupakan salah satu penyakit dengan potensi menyebabkan fatalitas cukup tinggi. Kasus DBD dapat menyerang seluruh kelompok umur, akan tetapi sebagian besar kasus menyerang anak - anak (Kemenkes RI, 2017).

WHO melaporkan jumlah kasus penyakit DBD meningkat dari 2,2 juta pada tahun 2010 menjadi lebih dari 3,34 juta pada tahun 2016 (WHO, 2017). Tahun 2017 kasus DBD di Indonesia berjumlah 68. 407 kasus dengan jumlah kematian sebanyak 493 orang (Kemenkes RI, 2017). Di Provinsi NTB kasus DBD dilaporkan sebanyak 1.605 kasus pada tahun 2017 dan kasus meninggal karena DBD pada tahun 2017 sejumlah 4 orang dengan CFR 0,2 \% (Dinkes Prov.NTB, 2017).

Demam berdarah dengue adalah salah satu penyakit berbasis lingkungan yang dapat dicegah dengan melakukan pengendalian vektor. Munculnya penyakit ini berkaitan dengan kondisi lingkungan dan perilaku masyarakat (Kemenkes RI, 2017). Oleh karena itu pemberdayaan 
masyarakat di bidang kesehatan sangatlah penting untuk mencegah penyakit, meningkatkan usia hidup dan meningkatkan kesehatan masyarakat serta keberhasilan upaya pencegahan memerlukan partisipasi aktif dari seluruh elemen masyarakat termasuk anak usia sekolah (WHO,2012; Kemenkes RI, 2014).

Upaya pencegahan dapat dilakukan dengan memberikan edukasi kepada masyarakat mengenai penyakit DBD dalam hal ini adalah anak usia sekolah. Salah satu metode pemberian edukasi ini adalah dengan menggunakan Board game sehingga diharapkan adanya peningkatan pengetahuan masyarakat, terutama siswa sekolah yang diikuti dengan perubahan sikap dan perilaku yang baik dalam upaya pencegahan Demam Berdarah melalui media permainan edukatif.

\section{METODE KEGIATAN}

Pencegahan penyakit DBD di masyarakat, termasuk anak sekolah dapat dilakukan dengan memberikan edukasi. Penyampaian informasi dapat dilakukan dengan cara yang menarik sehingga penerima informasi dapat memahami informasi tersebut dengan baik, terutama anak usia sekolah. Salah satunya adalah dengan menggunakan Board game yang dirancang sedemikian rupa dan menarik sehingga siswa akan dapat menerima pengetahuan tentang penyakit DBD ini dengan sangat menyenangkan tanpa ada rasa jenuh.

Kegiatan pengabdian masyarakat ini dilaksanakan dalam bentuk pemberian edukasi kepada guru dan siswa sekolah dengan menggunakan Board game. Peserta diperkenalkan dan diajarkan cara untuk memainkannya. Kemudian peserta diajak bermain dimana dalam permainan ini terdapat hal-hal yang bersifat edukatif mengenai penyakit DBD, sehingga semua informasi tentang demam berdarah dapat tersampaikan setelah peserta menyelesaikan permainan ini.

\section{HASIL DAN PEMBAHASAN}

Peserta kegiatan pengabdian ini adalah guru dan siswa SDN 16 Mataram yang berjumlah 34 orang dan kegiatan dilakukan di ruangan kelas. Guru dan siswa diperkenalkan dengan media edukasi berupa Board game dan diajarkan untuk memainkannya. Setelah itu guru dan siswa mempraktekkan sendiri untuk memainkan Board game dimana di dalam permainan ini peserta akan dapat mempelajari/mengetahui hal-hal yang bersifat informatif dan edukatif mengenai penyakit DBD, sehingga secara tidak langsung semua informasi mengenai DBD dapat diterima dengan baik oleh peserta setelah memainkan Board game ini.

Hasil dari kegiatan ini adalah seluruh peserta yang terdiri dari siswa dan guru SDN 16 Mataram sangat antusias untuk ikut berpartisipasi dalam kegiatan edukasi yang dikemas dalam bentuk permainan Board game ini. Siswa sekolah sangat menyukai dan menerima dengan baik edukasi melalui permainan ini karena siswa dapat memperoleh pengetahuan mengenai DBD dengan cara yang menyenangkan dan tidak merasa jenuh serta cenderung ingin memainkan kembali.

Dengan ketidaktersediaan vaksin dan terapi yang definitif untuk demam berdarah maka upaya pengendalian vektor nyamuk Aedes $s p$ sebagai perantara virus dengue masih menjadi sasaran upaya preventif (WHO,2012). Kegiatan pencegahan dapat dilakukan dengan memberikan edukasi kepada masyarakat, salah satunya adalah metode dengan Board game atau permainan papan. Metode ini menjadi salah satu alternatif metode pembelajaran di samping metode konvensional seperti ceramah dan diskusi (Giannakos, 2013). Keunggulan utama permainan papan adalah 
menyenangkan serta mengandung unsur permainan sehingga dapat meningkatkan luaran kognitif dan perilaku yang diharapkan dari permainan tersebut (Giannakos,2013; Ober, 2016).
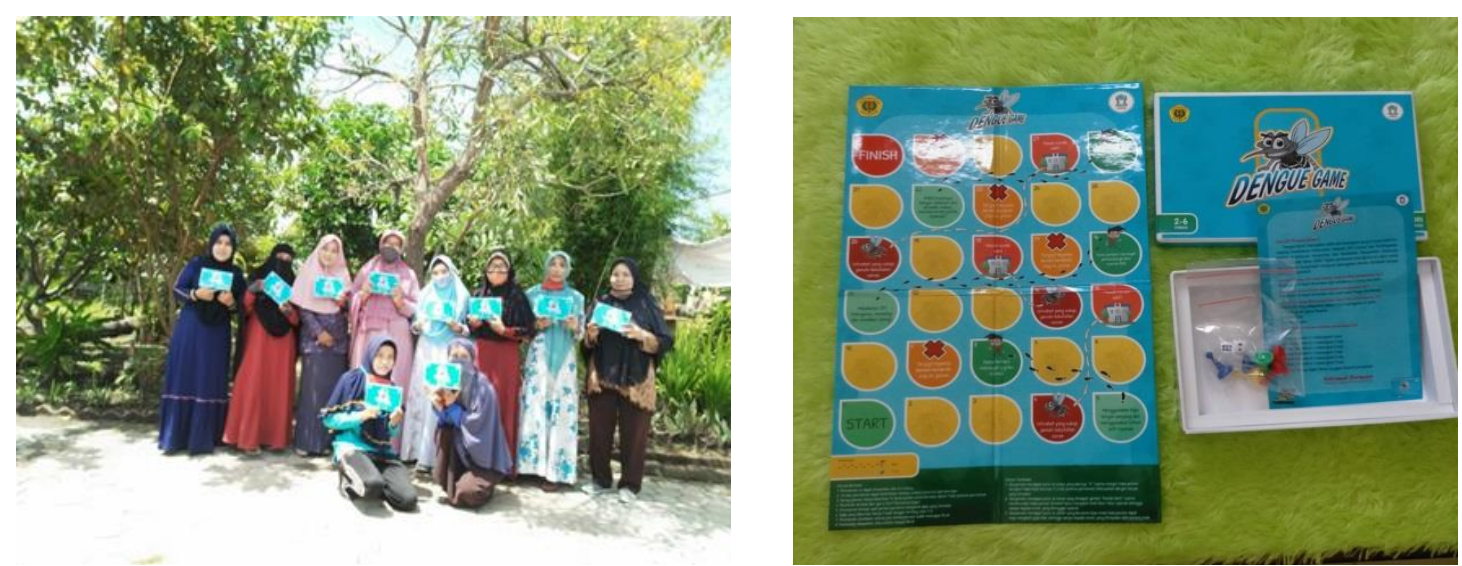

Gambar 1. Foto Bersama Para Guru dan Contoh Board Game
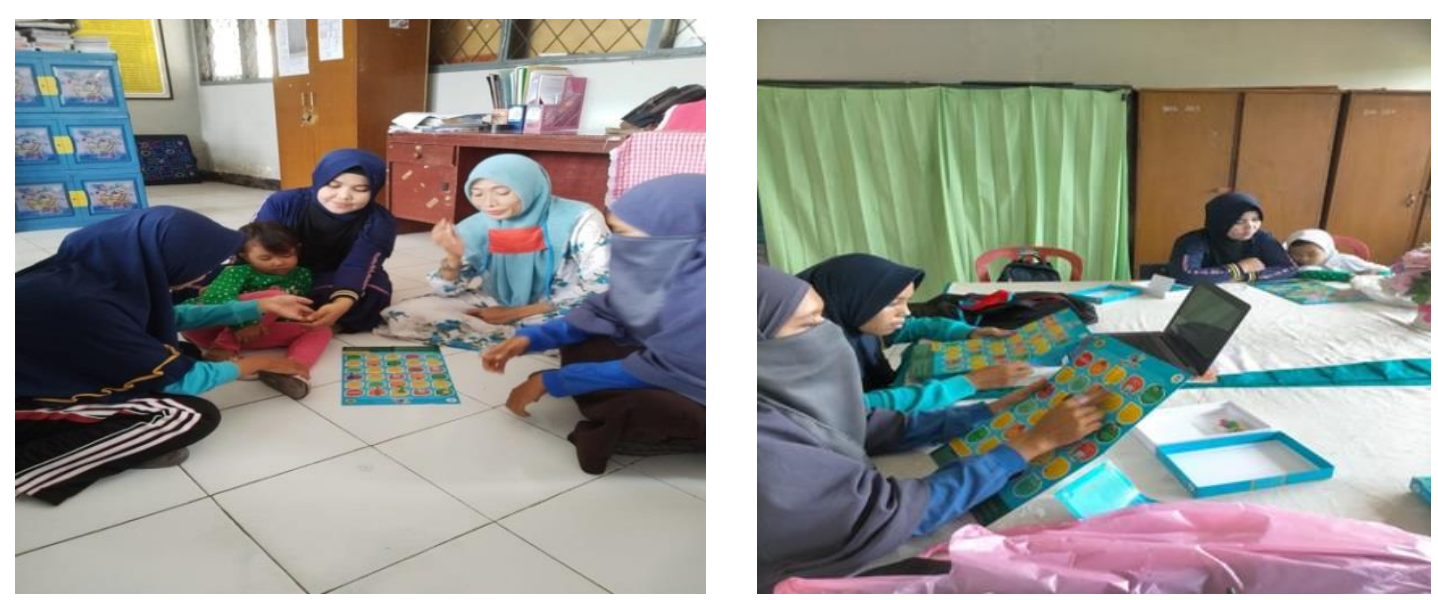

Gambar 2. Foto Peserta saat berlatih dan memainan Board Game

\section{KESIMPULAN DAN SARAN}

Pendidikan kesehatan berupa edukasi melalui permainan Board game dapat diterima dengan sangat baik oleh siswa sehingga mampu meningkatkan pengetahuan dan sikap siswa tentang pentingnya pencegahan penyakit dalam hal ini adalah demam berdarah. Kegiatan edukasi yang menarik lainnya dapat dilakukan untuk memberikan informasi kepada anak usia sekolah.

\section{UCAPAN TERIMA KASIH}

Penulis mengucapkan terima kasih kepada Kepala sekolah, para guru dan siswa SDN 16 Mataram yang telah memberikan ijin dan dukungan pada kegiatan pengabdian ini. Terima kasih kepada Lembaga Penelitian dan Pengabdian Kepada Mayarakat (LPPM) Universitas Mataram yang telah memberikan dukungan financial terhadap pengabdian ini. Terima kasih pula kepada Teman Sejawat, mahasiswa kedokteran serta seluruh pihak yang telah membantu dalam pelaksanaan kegiatan pengabdian ini. 


\section{DAFTAR PUSTAKA}

Giannakos M.N,. 2013. "Enjoy and learn with educational games: Examining factors affecting learning performance". Computers \& Education, 68:429 - 439.

KEMENKES RI. 2014. Petunjuk Teknis Jumantik-PSN Anak Sekolah.

Kemenkes RI. 2017. Data dan Informasi. Profil Kesehatan Indonesia 2017.

Nazri, C., Hashim, A. Rodziah, I., \& Hassan, A. Y. 2013. Utilization of geoinformation tools for dengue control management strategy: a case study in Seberang Prai, Penang Malaysia. International Journal of Remote Sensing Aplications, 3(1): 11-17.

Ober, C. P. 2016. Assessment of Student Engagement When Using a Novel Board Game for Teaching Thoracic Radiography to Fourth-Year Veterinary Students. Medical Science Educator, 26(1):39-42.

WHO. 2017. Dengue. http://www.who.int/denguecontrol/en/, diakses tgl 26 November 2020. WHO. 2012. Global Strategy for Dengue Prevention and Control 2012-2020. 